\title{
INTENSITY OF GROWTH, PRODUCTIVITY AND BODY CONDITION SCORE OF YOUNG BREEDING ANIMALS OF THE THRACIAN MERINO BREED
}

\author{
Petya Slavova $^{{ }^{*}}$, Nedka Dimova ${ }^{1}$, Milena Mihaylova ${ }^{1}$, Yovka Popova $^{1}$, Staika Laleva $^{1}$, \\ Nikola Pacinovski ${ }^{2}$, Stanimira Slavova ${ }^{1}$ \\ ${ }^{1}$ Agricultural Institute of Stara Zagora, 6000 Stara Zagora, Republic of Bulgaria \\ ${ }^{2}$ Institute of Animal Science, "Ss. Cyril and Methodius" University in Skopje, \\ Blvd. Ilinden 92a, Skopje, Republic of Macedonia \\ pkslavova@abv.bg
}

\begin{abstract}
A b s t r a c t: The study was carried out to establish dependence between some exterior measurements, productivity and body condition score (BCS) of ewe lambs from the Thracian merino breed, reared in the Agricultural Institute in Stara Zagora, Bulgaria. Ewe lambs included in the research were born during 2011-2015. The growth rate, as well as the main breeding traits as live weight, staple length, wool yield and pure fiber were studied, and body condition score was estimated at the age of 6,9 and 18 months. Conclusions: 1) The lambs of the Thracian merino breed had high growth rates at an early age. 2) The increase in body weight and bone mass is more intensive from 6 to 9 months of age, followed by the increase of the body condition score. 3) Productive traits as wool production, staple length, wool yield and pure fiber showed high level in ewe lambs at the age of 18 months, when they have their first breeding season.
\end{abstract}

Key words: body condition score; exterior measurements; ewe lambs; merino sheep; productive traits

\section{ИНТЕНЗИТЕТ НА ПРИРАСТ, ПРОДУКТИВНОСТ И ОЦЕНА НА ТЕЛЕСНАТА СОСТОЈБА КАЈ МЛАДИ РАСПЛОДНИ ЖИВОТНИ ОД ТРАКИСКАТА ТЕНКОРУНА РАСА ОВЦИ}

\begin{abstract}
А п с т р а к т: Беше проучувана врската помеѓу одредени екстериерни димензии, телесната состојба и продуктивноста кај млади приплодни животни од тракиската тенкоруна раса овци во Земјоделскиот институт во Стара Загора. Во испитување беа вклучени женски приплодни шилежиња од тракиската тенкоруна раса, родени во периодот 2011-2015 год. Проучуван е интензитетот на прирастот на јагнињата и е утврдено нивото на основните селекциски особни: жива маса, производство на волна, должина на волната, рандман и чистота на влакното, а оценета е и телесната состојба (ОТС) на три возрасти: 6, 9 и 18 месеци. Заклучоци: Јагнињата од тракиската тенкоруна раса се карактеризираат со висок интензитет на прираст во рана возраст. Зголемувањето на живата маса и коскениот систем е поинтензивно од 6 до 9-месечна возраст, што следствено значи и повисока оцена на телесната состојба. Продуктивните особини: производство на волна, должина, рандман на волна и чистота на влакното, на 18-месечна возраст кај тенкоруните животни се високи и одговараат на барањата кај благородни животни од тенкоруна популација.
\end{abstract}

Клучни зборови: оцена на телесната состојба; екстериерни димензии; женски шилежиња; мерино овци; продуктивни особини

\section{INTRODUCTION}

The performance of the productive traits in sheep populations is conditioned by the genetic changes resulting from the selection, the conditions of the environment and the physiological status of the animals. This also refers to endangered breeds, the conservation and maintenance of which requires the construction and implementation of an optimal breeding strategy. In recent years, the selection of merino sheep has been aimed at preserving their valuable characteristics and attaining a level of productivity consistent with the selection limits.

The intensity of the lamb's growth is an important productive trait closely related to the length of the period for achieving their weight for sale, which inevitably reflects the economic performance 
of the production activity. Researches on the growing abilities of merino lambs in our country have been conducted by Staikova et al. (2013), Iliev (2010), Tsonev (2014) etc.

The method for assessing the 6ody condition score (BCS) is defined by Russel et al. (1969) and allows for expert and express evaluation of the animals and analysis of its compliance with the physiological status required for a physiological status. It provides information on the level of nutrition and allows for its correction in relation to animals' development the production of sheep products. Establishing the influence and interdependence between $\mathrm{BCS}$ and productive traits allows the management of the breeding process to increase productivity (Kott, 2008), preserving sheep's health. Over the last decade, studies in this area have been conducted by Hatcher et al. (2007); Sejian et al. (2009); Yilmaz et al. (2009), Cam et al. (2010) etc. In Bulgaria, the study of these dependencies is relatively limited and is mainly found in sheep of Thracian merino and Caucasus merino breeds (Slavova et al., 2010, 2011; Slavova, 2015; Staikova et al., 2013), as well as in sheep of the Bulgarian Dairy Synthetic Population (Dimova et al., 2008; Stancheva et al., 2013; Slavova et al., 2013).

The resulting scientific information from the studies and analyses in this field have a practical meaning, making them topical and necessary.

The aim of the present study is to establish dependence between physical conditions, productivity and some exterior dimensions in young breeding animals from Thracian merino breed.

\section{MATERIAL AND METHODS}

The research includes 99 female breeding ewe lambs from the Thracian merino breed, born during 2011-2015.

Determination of body condition score is performed at three ages as follows: $1^{\text {st }}$ at 6 months, $2^{\text {nd }}$ at 9 months and $3^{\text {rd }}$ at 18 months. The following exterior measurements of the animals were done as well: body length, withers height, breast depth, croup width, breast width and breast range. The body volume in $\mathrm{dm}^{3}$ was calculated by the formula of Oregui et al. (1991):

$$
\begin{gathered}
\text { Body volume }= \\
=\text { body length } \times \text { breast depth } \times \text { croup width }
\end{gathered}
$$

The survey information is based on the controls on productivity performed, following the instructions of the merino sheep. The intensity of growth in lambs from birth to 70-th days of age has been studied, as well as the level of the main selection traits - wool production, staple length, wool yield and pure fiber at 18 months.

Determination of body condition score is performed according to the accepted five-score system, denoted by numbers from 1 (very weak) to 5 (fattened) (Todorov, N., 2008; Todorov, N. et al., 1994; Thompson, J. and N. Meyer, 1994).

The data is processed with STATISTICA software.

\section{RESULTS AND DISCUSSION}

It is very important for science and practice to establish the intensity of lambs' growth till weaning, which is related to the possibility of their sale and revenue. Live weight at birth is $3.541 \mathrm{~kg}$ and gradually increases to $6.404 \mathrm{~kg}$ at 10 days of age, 11.997 $\mathrm{kg}$ at 30 days and reaches $21.318 \mathrm{~kg}$ at 70 days of age (Table 1). This is the suckling period, when the mother's effect is mainly taken into account through milk productivity and maternal qualities.

The established values of the trait in the current study are lower at birth but higher at the other ages in comparison with the pointed out by Tsonev (2014) in lambs from other merino breeds.

Table 1

\section{Live weight of lambs from Thracian merino breed at different ages $(n=99)$}

\begin{tabular}{lccccc}
\hline \hline Production traits & $n$ & $x \pm S x$ & $S$ & $C$ \\
\hline Live weight $(\mathrm{kg})$ & & & & & \\
\hline - at birth & 99 & $3.541 \pm 0.075$ & 0.742 & 20.95 \\
- at 10 days & 99 & $6.404 \pm 0.129$ & 1.286 & 20.08 \\
- at 30 days & 99 & $11.997 \pm 0.219$ & 2.177 & 18.15 \\
- at 70 days & 99 & $21.318 \pm 0.304$ & 3.029 & 14.21 \\
\hline Average daily gain $(\mathrm{kg})$ & & & & \\
\hline - at 10 days & 99 & 0.318 & & \\
- at 30 days & 99 & 0.294 & & \\
- at 70 days & 99 & 0.239 & & \\
\hline \hline
\end{tabular}

The average daily gain from birth to $10^{\text {th }}$ day is $0.318 \mathrm{~kg}$, from $10^{\text {th }}$ to $30^{\text {th }}$ day $-0.294 \mathrm{~kg}$, and from $30^{\text {th }}$ to $70^{\text {th }}$ day of age $-0.239 \mathrm{~kg}$. The data show high growth intensity after birth, which gradually decreases with the age. The level of this trait is relatively high for this breed. 
In a study, Tsonev (2014) established an average daily gain during the suckling period of 0.274 $\mathrm{kg}$ in lambs of merino breeds in Bulgaria.

The live weight of the animals at the age of 6 , 9 and 18 months when the body condition score assessment is performed, is shown on Figure 1.

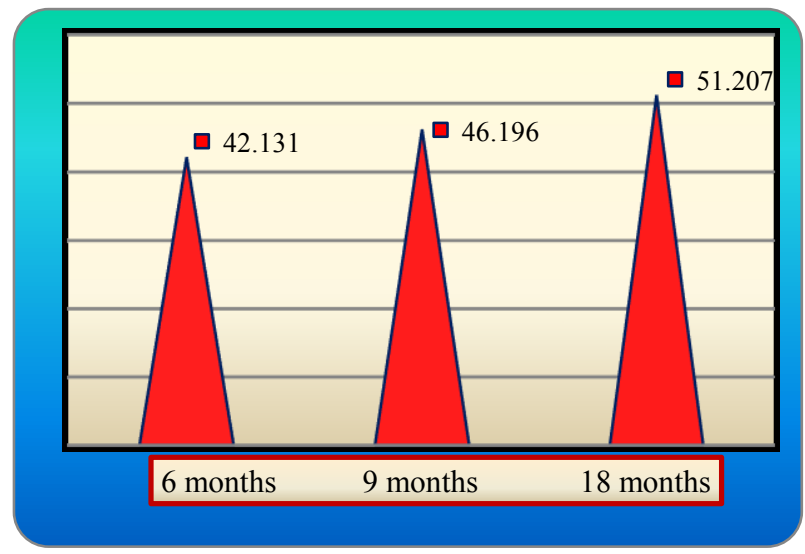

Fig. 1. Live weight at different ages, $\mathrm{kg}$

The value of the productive trait increases from $42.131 \mathrm{~kg}$ in 6 months to $46.196 \mathrm{~kg}$ in 9 months, at 18 months reaches $51.207 \mathrm{~kg}$. Intensity of growth is more significant in the first stage - up to 9 months, which is related to the better feed and climate conditions. The results for the live weight level show good body development of the young breeding animals and meet the criteria for animals of high selection.

The values of live weight established in our study at the age of 9 months are higher and at 18 months lower than those reported by Staikova et al. (2013) in young breeding animals of the Caucasian merino breed and by Iliev (2010) for the Karnobat merino breed.

Figure 2 shows the body condition score in the analyzed periods of age. It increases from 3.00 at 6 months to 3.016 at 9 months. Its value records a decrease at 18 months -2.978 , but it is an indicator of the appropriate physiological status, required for the successful inclusion of animals in the breeding process.

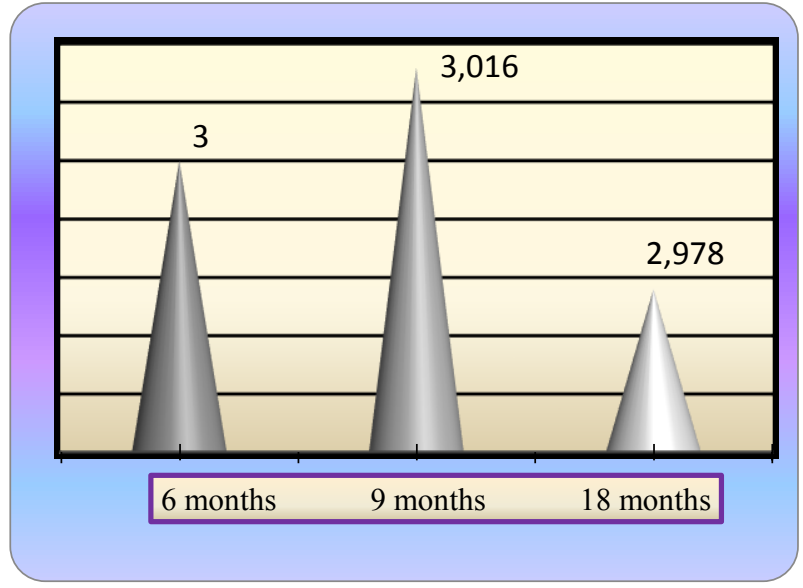

Fig. 2. Body condition score assessment for the overall period

Close to our results for estimation of body condition score of ewe lambs at $18^{\text {th }}$ months from the Caucasian merino breed have been reported by Staikova et al. (2013) - 2.75 .

The exterior measurements of the animals for the three different ages are shown in Table 2. There is a more intensive increase in the bone system over the period from 6 to 9 months and a slowdown from 9 to 18 months.

Table 2

External measurements of ewe lambs born

\begin{tabular}{l|cc:|cc|cc}
\hline \hline \multirow{2}{*}{ External measurements } & \multicolumn{2}{|c|}{$\begin{array}{c}\text { At } 6 \text { months } \\
n=99\end{array}$} & \multicolumn{2}{|c}{$\begin{array}{c}\text { At } 9 \text { months } \\
n=92\end{array}$} & \multicolumn{2}{c}{$\begin{array}{c}\text { At } 18 \text { months } \\
n=67\end{array}$} \\
& $\mathrm{x} \pm \mathrm{Sx}$ & $\mathrm{C}$ & $\mathrm{x} \pm \mathrm{Sx}$ & $\mathrm{C}$ & $x \pm S x$ & $C$ \\
\hline Body length, cm & $67.939 \pm 0.299$ & 4.38 & $70.875 \pm 0.214$ & 2.89 & $73.657 \pm 0.388$ & 4.31 \\
Withers height, cm & $66.919 \pm 0.456$ & 6.77 & $70.332 \pm 0.232$ & 3.16 & $73.224 \pm 0.238$ & 2.66 \\
Breast depth, cm & $26.010 \pm 0.141$ & 5.39 & $28.147 \pm 0.135$ & 4.61 & $29.478 \pm 0.125$ & 3.46 \\
Croup width, cm & $21.081 \pm 0.181$ & 8.44 & $22.576 \pm 0.175$ & 7.44 & $24.955 \pm 0.357$ & 11.73 \\
Breast width, cm & $19.783 \pm 0.145$ & 7.28 & $20.707 \pm 0.152$ & 7.04 & $22.104 \pm 0.205$ & 7.60 \\
Breast range, cm & $79.864 \pm 0.573$ & 7.13 & $85.652 \pm 0.503$ & 5.63 & $90.373 \pm 0.739$ & 6.70 \\
Body volume, dm & $37.463 \pm 0.562$ & 14.93 & $44.693 \pm 0.633$ & 14.01 & $52.396 \pm 0.853$ & 13.33 \\
\hline \hline
\end{tabular}


The reasons are both physiological and climatic. In the autumn-winter season (corresponding to the second period of growth and measurement) the influence of temperature, humidity and microclimate in the premises is essential. Most of the energy that animals receive through rations is directed to maintaining body temperature and physiological functions, and less to the growth of the bone system. The indicated growth rate and level of the studied traits is normal and inherent for the breed.

At 18 months, the levels of the other major breeding traits are also recorded - wool production, staple length, yield and pure fiber (Table 3).

Table 3

Wool production of the young breeding animals at 18-months of age $(n-91)$

\begin{tabular}{lccc}
\hline \hline Production traits & $x \pm S x$ & $S$ & $C$ \\
\hline Wool production, kg & $9.048 \pm 0.118$ & 1.125 & 12.43 \\
Staple length, cm & $15.430 \pm 0.243$ & 2.317 & 15.02 \\
Wool yield, \% & $56.996 \pm 0.660$ & 6.294 & 11.04 \\
Pure fiber, kg & $5.158 \pm 0.093$ & 0.889 & 17.24 \\
\hline \hline
\end{tabular}

The wool production averages $9.048 \mathrm{~kg}$, the staple length is $15.430 \mathrm{~cm}$, the wool yield is $56.996 \%$ and the pure fiber is $5.158 \mathrm{~kg}$. The values of the productive traits are high and correspond to the selection limits for animals of high selection from the merino breeds, laid down in the selection program.

Tsonev (2014) reports for similar to our results $-8.44 \mathrm{~kg}$ of wool production and 56.32 wool yield in 53 merino sheep flocks and Iliev (2010) reports for $8.83 \mathrm{~kg}$ wool production, $16.1 \mathrm{~cm}$ staple length and $57.31 \%$ wool yield in sheep from Karnobat merino breed.

\section{CONCLUSION}

The lambs of the Thracian merino breed have high growth intensity at early ages, which is due to the maternal effect.

The increase in body weight and bone mass is more intensive from 6 to 9 months of age and follows the increase in Bbody condition score. At 18 months, BCS decreases with the increase of live weight. The level of the two parameters analyzed shows that animals have the appropriate physiological status to be included in the breeding process.
Productive traits as wool production, staple length, wool yield and pure fiber at 18 months of age in merino sheep are high and meet the requirements for animals of high selection.

\section{REFERENCES}

[1] Cam, M. A., Olfaz, M., Sovdan, E.: Possibilities of using morphometrics characteristics as a tool for body weight prediction in Turkish hair goats, Asian Journal of Animals and Veterinary Advances, V. 5. Iss. 1, 52-59 (2010).

[2] Dimova, N., Ivanova, I., Peeva, J., Djorbineva, M., Mihaylova, M.: Variation in Body Condition Score and live weight in ewes in different physiological status, International Scientific Conference in SUB Stara Zagora, Agricultural science, 2008.

[3] Iliev, M.: Productive characteristic of sheep from the Karnobat merino breed, Journal of Animal Science, XLVII, 2, 22-27 (2010).

[4] Hatcher, S., Graham, P., Nielsen, S., Gilmour, A.: Fat score of ewes at joining: the benifits of optimal nutriation, 2007, www.dpi.nsw.gov.au.

[5] Kott, R.: Montana Farm Flock Sheep Production Handbook, Nutrition Part 2, Section 6 of 7, 2008.

[6] Oregui, L., Vicente, M. S., Garro, J., Bravo, V.: The relationship between body condition score and body weight in Laxta ewes, Options Mediterranéennes, 13, 109-112 (1991).

[7] Russel, A. J. F., Doney, J. M., Gunn, R. G.: Subjective assessement of body fat in live sheep. Journal of Agricultural Science, Cambridge, 72, 451-454 (1969).

[8] Sejian, V., Maurya, V. P., Naqvi, S. M. K., Kumar, D., Joshi, A.: Effect of induced body condition score differrences on physiological response, productive and reproductive performance of Malpura ewes kept in a hot, semiarid environment, J. Anim. Nutr, 94, 154-161 (2009).

[9] Slavova, P., Dimova, N., Ivanova, I., Peeva, J., Laleva, S., Popova, Y., Vasilev, V.: Relationship of reproduction performance with body condition score and wool production in ewes of Thracian fine-fleece breed, $X X^{\text {th }}$ International Scientific Conference: Science \& Technologies, Agricultural Science, Animal Studies \& Veterinary medicine, 5, 68-75, 2010.

[10] Slavova, P., Dimova, N., Peeva, J., Laleva, S., Popova, Y.: Investigation of the relationship between some body measurements with body condition score and production performance in sheep of Thracian fine-fleece breed, Science \& Technologies, V. 1, 5. Animal Studies \& Veterinary medicine, 64-70 (2011).

[11] Slavova, P., Dimova, N., Laleva, S., Peeva, J., Mihaylova, M.: Study relationship between body condition score, live weight and fertility on dairy sheep, Science \& Technologies, V 3, № 5, Animal Studies \& Veterinary Medicine, 6570 (2013).

[12] Slavova, P.: Study of the possibility to optimize fertility and body condition score in sheep of Thracia merino breed, Science \& Technologies, V 5, № 5 Animal Studies \& Veterinary Medicine, 28-35 (2015).

[13] Staikova, G., Stancheva, N.: Effect of different sources of specific variability on live weight and fertility traits in 
Cacasian merino breed, Journal of Animal Science, 5, 13,: 43-50 (2013).

[14] Stancheva, N., Staikova, G.: Body condition score and productive performance of the Syntetic population Bulgarian milk sheep, Journal of Animal Science, L. 6, 42-46 (2013).

[15] Staikova, G., Penchev, P., Stancheva, N.: Interrelationship between body condition score at different physiological statuses and some economic traits in the Caucasian sheep breed, Bulgarian Journal of Agricultural Science, 19 (5), 1105-1111 (2013).

[16] Todorov, N., Mitev, Y., Otuzbirov, R.: Assessment of body condition score in sheep, NIS in VIZVM, Stara Zagora, 1994.
[17] Todorov, N.: Feeding and Raising in Sheep, Matkom, Sofia, 2008

[18] Thomson, J., Meyer, H.: Body Condition Scoring of Sheep, 1994, http://extension.oregonstate.edu/catalog/pdf/ec/ec1 433.pdf

[19] Tsonev, T.: Productive characteristics of merino sheep breeding in Bulgaria, PHD thesiss, 2014.

[20] Yilmaz, M., Altin, T., Onur, Y., Cemal, I., Bardakciogly, H.E., Taskin, T., Karaca, O.: The Effect of Body Condition Score at mating on the Reproductive Performance of Kivircik Sheep under Extensive Production System, IV Balkan Conference of Animal Science, Balnimalcon, Proceedings: 57-62, 2009. 
